\title{
Peningkatan Kemampuan Pemecahan Masalah Matematik Siswa SMA melalui Pembelajaran Matematika dengan Strategi Kooperatif Tipe STAD
}

\author{
Siswadi* \\ Jurusan Pendidikan Matematika, Universitas Alwashliyah \\ siswady12smile@gmail.com
}

\begin{abstract}
This study aims to see how the efforts in improving the mathematical problem solving ability of high school students by learning STAD type cooperative strategies. This research is based on the importance of mathematical problem solving abilities that must be possessed by students, but the reality on the ground that these abilities are still very low. This research is an experiment with a pretest-posttest control group design. This is done in order to find out how much improvement in the ability to solve mathematical problems taught by learning mathematics in STAD type cooperative strategies. For the experimental group, students are taught with STAD type cooperative strategies, while in the control group, students are taught by direct learning. The population of this study was high school students, while the sample was students of class XI IPA of Laksamana Martadinata Medan Private High School. Five classes were randomly selected, class XI IPA 3 class as the experimental class and XI IPA 1 as the control class. The instrument used in the form of problem solving problems. Based on the results of the analysis, it can be concluded that: 1) there is a mean difference between students who are taught with STAD type cooperative strategies and those who are in direct learning. 2) Improvement of students' mathematical problem solving abilities that get cooperative learning type STAD gets direct learning ineffective.
\end{abstract}

Keywords: STAD; mathematics learning; direct learning; mathematical problems; problem solving ability

\begin{abstract}
Abstrak
Penelitian ini bertujuan melihat bagaimana upaya meningkatkan kemampuan pemecahan masalah matematika siswa SMA dengan pembelajaran strategi kooperatif Tipe STAD. Penelitian ini didasarkan pada pentingnya kemampuan pemecahan masalah matematik yang harus dimiliki oleh siswa, kenyataan di lapangan bahwa kemampuan tersebut masih sangat rendah. Jenis penelitian ini adalah eksperimen dengan desain kelompok kontrol pretes-postes. Hal ini dilakukan guna mengetahui seberapa besar peningkatan kemampuan pemecahan masalah matematik yang diajar dengan pembelajaran matematika strategi kooperatif Tipe STAD. Kelompok eksperimen, siswa diajar dengan strategi kooperatif tipe STAD, sementara pada kelompok kontrol, diajar dengan pembelajaran langsung. Populasi penelitian adalah siswa SMA, sampelnya adalah siswa kelas XI IPA SMA Swasta Laksamana Martadinata Medan. Lima kelas dipilih secara acak, kelas XI IPA 3 kelas sebagai kelas eksperimen dan XI IPA 1 sebagai kelas kontrol. Instrumen yang digunakan berupa soal pemecahan masalah. Berdasarkan hasil analisis, disimpulkan bahwa: 1). terdapat perbedaan rerata antara siswa yang diajar dengan strategi kooperatif tipe STAD dengan yang pembelajaran langsung. 2) peningkatan kemampuan pemecahan masalah matematik siswa yang mendapat pembelajaran kooperatif Tipe STAD mendapat pembelajaran langsung tidak efektif.
\end{abstract}

Kata Kunci: STAD; pembelajaran matematika; pembelajaran langsung; masalah matemtika: kemamnuan nemecahan masalah

\footnotetext{
*Correspondence:

Email: siswady12smile@gmail.com
} 


\section{PENDAHULUAN}

Pemecahan masalah merupakan salah satu kemampuan yang harus dikuasai oleh peserta didik/siswa setelah belajar matematika. Dengan demikian diharapkan bahwa ketika siswa menghadapi permasalahan matematika dalam kegiatan pembelajaran siswa tersebut mampu untuk memecahkan masalah dengan tepat dan baik. Kemudian siswa juga diharapkan akan mampu dalam menyelesaikan permasalahan dalam kehidupan real atau nyata setelah menempuh pendidikan formal.

Tujuan utama dari kegiatan pembelajaran matematika tingkat sekolah di negara-negara maju menjadikan kemampuan pemecahan masalah matematis sebagai tujuan (goal) utama dari suatu kegiatan pembelajaran matematika di sekolah. Hal ini diprediksi bahwa ketika siswa memiliki kemampuan pemecahan masalah matematis yang baik, maka akan mampu memberikan berkontribusi terhadap perkembangan perekonomian bangsanya.

Berlandaskan pada (NCTM, 2000) kemampuan pemecahan masalah matematis merupakan salah satu tujuan (goal) yang harus dicapai dalam kegiatan pembelajaran, yang kemudian NCTM menetapkan 5 (lima) tujuan pembelajaran di sekolah, yaitu: (1) komunikasi matematis, (2) penalaran matematis, (3) pemecahan masalah matematis, (4) koneksi matematis, dan (5) representasi matematis. Kemampuan pemecahan masalah juga ditegaskan dalam NCTM bahwa kemampuan pemecahan masalah merupakan bagian yang tidak dapat dipisahkan dalam proses pembelajaran matematika di sekolah, dengan demikian pemecahan masalah matematis tidak bisa dilepaskan dari kegiatan pembelajaran matematika.

Secara umum, tujuan pembelajaran matematika di sekolah adalah untuk memenuhi kebutuhan praktis dan memecahkan masalah dalam kehidupan seharihari, mempersiapkan diri siswa agar sanggup menghadapi perubahan kehidupan dan dunia yang selalu berkembang dan sarat perubahan, melalui latihan bertindak atas dasar pemikiran logis, rasional, dan kritis. Berdasarkan tujuan tersebut tampak bahwa arah atau orientasi pembelajaran matematika adalah kemampuan pemecahan masalah matematika. Kemampuan pemecahan masalah sangat berguna bagi siswa dalam kehidupan sehari-hari maupun pada saat mendalami matematika itu sendiri.

Pemecahan masalah merupakan bagian dari kurikulum matematika yang sangat penting karena dalam proses pembelajaran maupun penyelesaian, siswa dimungkinkan memperoleh pengalaman menggunakan pengetahuan serta keterampilan yang sudah dimiliki untuk diterapkan pada pemecahan masalah yang bersifat tidak rutin. Melalui kegiatan ini aspek-aspek kemampuan matematika penting seperti penerapan aturan pada masalah tidak rutin, penemuan pola, 
penggeneralisasian, komunikasi matematik, dan lain-lain dapat dikembangkan secara lebih baik (Suherman, 2003).

Sumarmo (Sumarmo, 1994) menyatakan bahwa pemecahan masalah merupakan hal yang sangat penting sehingga menjadi tujuan umum pengajaran matematika bahkan sebagai jantungnya matematika. Hal ini senada juga dengan laporan penelitian yang dibuat oleh NCTM tahun 2010 yaitu bahwa problem solving an important role in mathematic and should have prominent role in mathematics education yang artinya bahwa pemecahan masalah memiliki peranan penting dalam matematika dan dalam pendidikan matematika.

Naman kenyataan berdasarkan dari hasil tes dan evaluasi PISA performa siswa-siswi Indonesia masih tergolong rendah. Perbandingan skor PISA Indonesia untuk periode 2015 dan 2018. Skor kemampuan membaca turun dari 397 poin ke 371 poin. Kemudian kemampuan matematika turun dari 386 poin ke 379 poin. Lalu kemampuan sains turun dari 403 poin ke 396 poin. Akibat dari raihan itu, ranking PISA Indonesia turun dari urutan ke-72 menjadi ke-77 (PISA, 2016). Salah satu penyebab utama yang membuat rendahnya prestasi siswa Indonesia dalam peringkat PISA adalah lemahnya kemampuan dalam memecahkan masalah non-routine atau dikategorikan masalah level tinggi..

Menurut (Siswadi, 2018) masalah adalah suatu situasi dimana ada sesuatu yang kita inginkan, tetapi tidak tahu bagaimana mendapatkannya atau mencapainya supaya sampai pada tujuan atau keinginan tersebut tidak sesuai kenyataan. Pemecahan masalah adalah suatu kegiatan dalam menanggulangi kesulitan-kesulitan yang dijumpai untuk mencapai suatu tujuan yang diinginkan (Sumarmo, 2010). Selanjutnya (Sukayasa, 2012) menjelaskan pengertian lebih umum dari pemecahan masalah adalah kegiatan penerimaan masalah sebagai suatu tantangan untuk menyelesaikannya. pemecahan masalah tentu saja selalu berangkat dari permasalahan itu sendiri. Masalah adalah suatu ketimpangan antara apa yang diinginkan/diharapkan dengan kenyataan yang terjadi.

Kemudian menurut (Pimta, 2009) pemecahan masalah ditandai sebagai jantung untuk belajar matematika karena tidak hanya mempelajari subyek, tetapi menekankan pada pengembangan berpikir, keterampilan, dan metode yang digunakan. Dikatakan jantung karena melalui pemecahan masalah itu maka kemampuan kognitif siswa akan nampak.

Menurut (Polya, 1985) ada empat langkah yang mesti dijalankan dalam konsep peyelesaian soal pemecahan masalah, yaitu:

1. Memahami masalah, yang terdiri dari siswa memahami permasalahan yang diketahui dan hal hal yang ditanyakan.

2. Merancang rencana penyelesaiannya, yang kemudian dilakukan dengan menjabarkanya dalam bentuk kalimat matematika.

3. Melakukan penyelesaian masalah. 
4. Mencek kembali, hal ini memuat bagaimana cara menunjukan bahkan membuktikan bahwa penyelesaian yang telah dibuat tersebut benar kemudian disimpulkan hasil jawabannya.

Dari penjabaran tersebut, dapat disimpulkan bahwa kemampuan pemecahan masalah matematis begitu penting untuk diajarkan dan dikembangkan. Namun, pada faktanya kemampuan tersebut belum dikembangkan secara maksimal. Sangat diperlukan strategi pembelajaran kreatif dan inovatif sehingga mampu memotivasi keinginan belajar siswa, sehingga pembelajaran lebih bermakna, siswa menjadi lebih aktif dan mampu mengembangkan segala kemampuan yang dimilikinya. Salah satu alternatif model pembelajaran matematika yang diharapkan untuk dapat meningkatkan kemampuaan pemecahan masalah matematis adalah penggunaan strategi kooperatif tipe STAD.

Menurut Muslimin dkk. (dalam Widyantini, 2008) Strategi pembelajaran koperatif memiliki beberapa keunggulan di antaranya dapat meningkatkan pencurahan waktu dan tugas, sikap apatis berkurang, motivasi belajar mmeningkat, hasil belajar lebih tingi dan dapat mengurangi perilaku mengganggu. Sedangkan pendekatan investigasi dapat mendorong siswa bekerja secara bebas, memberi semangat untuk berinisiatif, kreatif, dan aktif, rasa percaya diri dapat lebih meningkat, belajar bekerjasama, berkomunikasi dengan teman sendiri maupun dengan guru (Setiawan, 2006). Selain itu, melalui fase-fase pembelajaran dengan pendekatan investigasi siswa dapat mengamati permasalahan, melihat pola, membuat dugaan dan merumuskan kesimpulan dari hasil investigasi (Setiawan, 2006). Proses ini dapat membantu siswa untuk memecahkan masalah dan sampai pada solusi dari suatu permasalahan.

Pembelajaran kooperatif tipe STAD bisa membantu siswa dalam memahami konsep materi yang dipelajari. Dalam strategi STAD siswa dibagi kedalam beberapa kelompok yang terdiri dari 4-6 orang dengan mengutamakan heterogenitas (keberagaman) siswa dalam prestasi akademik. Guru memberikan pembelajaran dan siswa di dalam kelompok diharapkan semua anggota kelompok itu mampu menguasai materi yang diajarkan. Yang pada akhirnya semua siswa menjalani kuis secara individual, mereka tidak diperkenankan membantu antara satu dengan lain (Siregar, Syahputra, \& Sriadhi, 2019). Ocampo \& Bascosocampo (Ocampo, R. O., \& Bascos-ocampo, 2015), menjelaskan bahwa strategi ini dapat merangsang tanggung jawab kelompok untuk mendorong pembelajaran individu.

Langkah-langkah dalam menerapkan strategi pembelajaran kooperatif tipe STAD dalam penelitian ini adalah 6 (enam) langkah yaitu: (1) membagi kelompok, (2) menyampaikan materi, (3) berdiskusi dalam kelompok, (4) memberikan kuis/pertanyaan, (5) menyimpulkan materi, (6) memberikan penghargaan (Wibowo, Rahmat, Wahyudi, 2016). 
Strategi pembelajaran STAD memiliki beberapa keunggulan, diantaranya sebagai berikut: semua anggota dalam kelompok wajib mendapatkan tugas, ada interaksi secara langsung antar siswa dengan siswa yang lain dan siswa dengan guru, siswa dilatih dalam mengembangkan keterampilan sosial, mendorong para siswa untuk menghargai setiap pendapat orang lain, mampu meningkatkan kemampuan akademik siswa dan melatih siswa untuk mampu dan berani bicara di depan kelas.

Keuntungan strategi pembelajaran kooperatif tipe STAD menurut (Roestiya, 2001), yaitu: 1) Dapat memberikan kesempatan kepada siswa untuk menggunakan keterampilan bertanya dan membahas suatu masalah. 2) Dapat memberikan kesempatan kepada siswa untuk lebih intensif mengadakan penyelidikan mengenai suatu masalah. 3) Dapat mengembangkan bakat kepemimpinan dan mengajarkan keterampilan berdiskusi. 4) Dapat memungkinkan guru untuk lebih memperhatikan siswa sebagai individu dan kebutuhan belajarnya. 5) Para siswa lebih aktif bergabung dalam pelajaran mereka dan mereka lebih aktif dalam diskusi. 6) Dapat memberikan kesempatan kepada siswa untuk mengembangkan rasa menghargai, menghormati pribadi temannya, dan menghargai pendapat orang lain.

\section{METODE PENELITIAN}

Peneliti ingin melihat peningkatan kemampuan pemecahan masalah matematik siswa yang disebabkan adanya suatu perlakuan pembelajaran dengan menggunakan desain penelitian eksperimen. Perlakuan yang diberikan berupa pembelajaran matematika dengan strategi kooperatif Tipe STAD sebagai variabel bebasnya, kemudian kemampuan pemecahan masalah matematik siswa dijadikan sebagai variabel yang diamati (variabel terikatnya). Secara singkat, desain dari penelitian eksperimen dapat dilihat pada tabel 1 dibawah ini.

Tabel 1. Desain Penelitian Eksperimen

\begin{tabular}{cccc}
\hline $\mathbf{A}$ & $\boldsymbol{O}_{\mathbf{1}}$ & $\boldsymbol{X}_{\mathbf{1}}$ & $\boldsymbol{O}_{\mathbf{2}}$ \\
\hline $\mathbf{A}$ & $O_{1}$ & $X_{2}$ & $O_{2}$ \\
\hline
\end{tabular}

Keterangan:

$X_{1}=$ model pembelajaran kooperatif Tipe STAD

$X_{2}=$ model pembelajaran langsung

$\mathrm{A}=$ sampel yang diambil secara acak

$O_{1}=$ nilai pretes

$\mathrm{O}_{2}=$ nilai postes 
Siswa SMA kelas XI SMA Laksamana Martadinata Medan menjadi populasi dalam penelitian ini. Hal ini karena siswa Kelas XI merupakan siswa menengah pada jenjangnya, penyesuaian terhadap lingkungan sekolahnya menjadi salah satu pilihan dalam kegiatan penelitian ini dibandingkan dengan siswa kelas $\mathrm{X}$ yang baru masuk pada tahun petamanya. Persiapan UN juga siswa SMA kelas XI tidak disibukkan dibandingkan dengan kelas XII, sehingga lebih mudah dalam mengaplikasikan pembelajaran yang lain dari pembelajaran pada umumnya. Jumlah keseluruan kelas XI adalah 9 kelas, kemudian terpilih 2 kelas secara random yang dijadikan sampel dalam penelitain ini. Dari hasil undian acak ini, terpilih kelas XI IPA 1 sebagai kelas kontrol dan kelas XI IPA 3 untuk kelas eksperimen yang masing-masing kelas jumlanya 38 siswa.

Tes sebagai instrumen yang digunakan dalam penelitian ini. Dalam mengukur kemampuan pemecahan masalah matematik, tes yang digunakan adalah tes kemampuan pemecahan masalah matematik berupa pretes dan postes. Sebelum tes ini digunakan dalam melakukan penelitian, awalnya soal diujicobakan pada kelas XII, untuk mengetahui tingkat kevalidanya, reliabel, daya beda, dan tingkat kesukarannya.

Penelitian ini memerlukan tahapan-tahapan dalam menganalisisnya. Langkah-langkahnya adalah sebagai berikut:

- Program SPSS versi 21.0 digunakan untuk menguji tingkat normalitas nilai dari pre dan postesnya untuk masing-masing kelompok sampel.

- Menguji homogenitas untuk setiap kelompok sampel guna mengetahui tingkatan varians yang homogen atau tidak. Seluruh uji yang digunakan dengan mendistribusikan data ke SPSS versi 21.0 sehingga menghasilkan output Test of Homogenity of Variances.

- Uji beda berpasangan digunakan SPSS 21.0 dengan membandingkan signifikansi hasil luaran data. Apabila nilai Signifikan $<0,05$ maka dapat ditarik kesimpulan terdapat perbedaan rerata kemampuan pemecahan masalah kelas eksperimen dengan kelas kontrol.

- Uji gain ternormalisasi (N-Gain) digunakan. Hal ini guna mengetahui apakah setelah diberi perlakuan terdapat peningkatan hasil belajar kognitif siswa. Nilai pretest dan posttest diambil untuk melihat peningkatan kemampuan pemecahan masalah tersebut. Perbandingan skor gain aktual dengan skor gain maksimum adalah nilai yang diambil dari Gain ternormalisasi atau yang disingkat dengan $N$-Gain. Dengan kriteria sebagai berikut: 
Tabel 2. Tafsiran Efektifitas N-Gain

\begin{tabular}{cc}
\hline Presentase $(\%)$ & Tafsiran \\
\hline$<\mathbf{4 0}$ & Tidak Efektif \\
\hline $\mathbf{4 0 - 5 5}$ & Kurang Efektif \\
\hline $\mathbf{5 6}-\mathbf{7 5}$ & Cukup Efektif \\
$>\mathbf{7 6}$ & Efektif \\
\hline & (Hake, R, 1999)
\end{tabular}

\section{HASIL DAN PEMBAHASAN}

Hasil kemampuan pemecahan masalah dari kelas eksperimen dan kelas kontrol perhitungan uji normalitas dapat dilihat pada tabel 3 berikut:

Tabel 3. Hasil Uji Normalitas Data (SPSS 21)

\begin{tabular}{ccccccc}
\hline & \multicolumn{3}{c}{ Kolmogorov-Smirnov ${ }^{\mathrm{a}}$} & \multicolumn{4}{c}{ Shapiro-Wilk } \\
\cline { 2 - 7 } & Stati & df & Sig. & Stati & df & Sig. \\
\hline Pretes eks &, 099 & 38 &, $200^{*}$ &, 971 & 38 &, 413 \\
\hline Postes eks &, 086 & 38 &, $200^{*}$ &, 972 & 38 &, 459 \\
\hline Pretes Kon &, 122 & 38 &, 161 &, 973 & 38 &, 468 \\
\hline Postes Kon &, 104 & 38 &, $200^{*}$ &, 977 & 38 &, 606 \\
\hline
\end{tabular}

Dasar pengambilan keputusanya adalah dengan membandingkan nilai Sig pada shapiro-wilk dengan 0,05. Jika nilai sig $>0,05$ maka data berdistribusi normal. Dari tabel di atas dapat disimpulkan bahwa semua data berdistribusi normal.

Setelah diuji normalitasnya, kemudian data diuji homogenitas variansinya, untuk mengetahui apakah kedua distribusi pada kelas eksperimen dan kelas kontrol mempunyai variansi yang homogen. Hasil perhitungan uji homogenitas variansi untuk kemampuan pemecahan masalah matematik pada kelas eksperimen dan kelas kontrol dapat dilihat pada tabel 4 berikut:

Tabel 4. Hasil Uji Homogenitas Data Pretes (SPSS 21)

Pretes

\begin{tabular}{cccc}
\hline Levene Statistic & df1 & df2 & Sig. \\
\hline, 092 & 1 & 74 &, 763 \\
\hline
\end{tabular}


Tabel 5. Hasil Uji Homogenitas Data Postest (SPSS 21)

Postes Eksperimen Kontrol

\begin{tabular}{cccc}
\hline Levene Statistic & df1 & df2 & Sig. \\
\hline, 342 & 1 & 74 &, 561 \\
\hline
\end{tabular}

Dasar pengambilan keputusan uji homogenitas adalah homogen jika nilai signifikansi $>0,05$. Dengan demikian dapat disimpulkan bahwa data pretes dan data postes kedua kelas berdistribusi homogen.

Selanjutnya untuk pengujian perbedaan rerata dapat dilakukan dengan uji statistik parametrik. Dalam hal ini peneliti menggunakan SPSS 21.0

Tabel 6. Hasil Uji Rerata Postest (SPSS 21)

Paired Samples Test

\begin{tabular}{|c|c|c|c|c|c|c|c|c|c|}
\hline & & \multicolumn{5}{|c|}{ Paired Differences } & \multirow{3}{*}{$\mathrm{T}$} & \multirow{3}{*}{ df } & \multirow{3}{*}{$\begin{array}{l}\text { Sig. (2- } \\
\text { tailed) }\end{array}$} \\
\hline & & \multirow[t]{2}{*}{ Mean } & \multirow[t]{2}{*}{$\begin{array}{c}\text { Std. } \\
\text { Deviation }\end{array}$} & \multirow{2}{*}{$\begin{array}{l}\text { Std. } \\
\text { Error } \\
\text { Mean }\end{array}$} & $\begin{array}{r}9 \\
\text { Conf } \\
\text { Interva } \\
\text { Diffe }\end{array}$ & $\begin{array}{l}5 \% \\
\text { idence } \\
1 \text { of the } \\
\text { rence }\end{array}$ & & & \\
\hline & & & & & $\begin{array}{l}\text { Lowe } \\
\text { r }\end{array}$ & Upper & & & \\
\hline $\begin{array}{c}\text { Pair } \\
1\end{array}$ & $\begin{array}{c}\text { Post_Eksperi } \\
\text { men - } \\
\text { Post_Kontrol }\end{array}$ & $\begin{array}{c}10,94 \\
737\end{array}$ & 12,44870 & $\begin{array}{c}2,019 \\
45\end{array}$ & $\begin{array}{c}6,855 \\
58\end{array}$ & $\begin{array}{c}15,039 \\
15\end{array}$ & $\begin{array}{c}5,42 \\
1\end{array}$ & 37 &, 000 \\
\hline
\end{tabular}

Dari tabel 6 di atas diperoleh nilai Sig. $<0,05$ maka dapat disimpulkan bahwa terdapat perbedaan rerata kemampuan pemecahan masalah kelas eksperimen dengan kelas kontrol.

Kemudian dilihat peningkatannya dari skor pretes terhadap skor postes di uji menggunkan Uji gain ternormalisasi (N-Gain) dengan bantuan SPSS 21. Hasil perhitungan peningkatan kemampuan pemecahan masalah matematik dari skor pretes ke skor postes untuk kelas eksperimen dan kelas kontrol dapat dilihat dari tabel 7 berikut ini: 
Tabel 7. N Gain Hasil Kemampuan Pemecahan Masalah Matematika Siswa (SPSS 21)

\section{Descriptives}

\begin{tabular}{|c|c|c|c|c|c|}
\hline & Kelas & & & Statistik & Satd. Error \\
\hline & & Rata-rata & & 29,6943 & 2,08485 \\
\hline & & $95 \%$ Confidence & Lower Bound & 25,4700 & \\
\hline & & Interval for Mean & Upper Bound & 33,9186 & \\
\hline & & 5\% Trimmed Mean & & 30,0402 & \\
\hline & & Median & & 31,9224 & \\
\hline & & Variance & & 165,170 & \\
\hline & Eksperimen & Std. Deviation & & 12,85185 & \\
\hline & & Min & &, 00 & \\
\hline & & Max & & 52,86 & \\
\hline & & Range & & 52,86 & \\
\hline & & Interquartile Range & & 19,87 & \\
\hline & & Skewness & &,- 351 & ,383 \\
\hline Ngain & & Kurtosis & &,- 333 & ,750 \\
\hline $\begin{array}{l}\text {-pers } \\
\text { en }\end{array}$ & & Mean & & 15,5730 & 1,96694 \\
\hline & & 95\% Confidence & Lower Bound & 11,5839 & \\
\hline & & Interval for Mean & Upper Bound & 19,5622 & \\
\hline & & $5 \%$ Trimmed Mean & & 15,3833 & \\
\hline & & $\mathrm{Me}$ & & 13,7500 & \\
\hline & & Variance & & 143,147 & \\
\hline & Kontrol & Std. Deviation & & 11,96441 & \\
\hline & & Min & & ,00 & \\
\hline & & $\operatorname{Max}$ & & 37,10 & \\
\hline & & Range & & 37,10 & \\
\hline & & Interquartile Range & & 24,14 & \\
\hline & & Skewness & &, 051 & ,388 \\
\hline & & Kurtosis & & $-1,538$ & ,759 \\
\hline
\end{tabular}


Dengan program SPSS 21 dihasilkan perhitungan uji ( $N$-Gain) menunjukan nilai rata-rata dari $N$-Gain score pada kelas eksperimen 29,6943 atau $29,7 \%$ tergolong dalam kategori tidak efektif dengan rentang nilai $\mathrm{N}$-Gain score terkecil adalah $0 \%$ dan terbesar adalah $52,85 \%$. Selanjutnya untuk nilai rata-rata $\mathrm{N}$-Gain kelas kontrol sebesar 15,5730 atau 15,6\% tergolong kategori tidak efektif dengan nilai $\mathrm{N}$-Gain terkecil adalah $0 \%$ dan terbesar adalah $37,10 \%$. Dengan demikian dapat disimpulkan bahwa penggunaan strategi kelompok tipe STAD maupun pembelajaran langsung dalam peningkatan kemampuan pemecahan masalah siswa SMA Martadinata kelas XI tidak efektif.

\section{KESIMPULAN}

Berdasarkan hasil penganalisisan dan pembahasan, maka bisa disimpulkan bahwa penggunaan strategi kelompok tipe STAD maupun pembelajaran langsung tidak efektif dalam peningkatan kemampuan pemecahan masalah siswa SMA Martadinata kelas XI. Tanggapan anak didik dalam penggunaan pembelajaran kelompok Tipe STAD adalah positif. Hal ini dapat dilihat dari penghitungan rerata skor siswa yang menunjukkan bahwa rerata skor siswa pembelajaran kelompok Tipe STAD lebih besar bila dibandingkan dengan mean skor model pembelajaran langsung. Pembelajaran matematika dengan strategi kooperatif Tipe STAD belum terbiasa bagi siswa. Hal ini mengakibatkan kurangnya tanggung jawab, kesiapan serta kesadaran tiap siswa dalam kelompok-kelompoknya, yaitu bagaimana cara ia harus mengambil giliran dan berbagi tugas; bagaimana ia harus mendorong siswa lain dalam satu kelompok untuk berpartisipasi; mereka masih sering belajar/bekerja dalam kelompoknya secara sendiri-sendiri sehingga persentase mendengarkan penjelasan teman dalam kelompoknya masih rendah; frekuensi pertanyaan-pertanyaan siswa lebih banyak ditujukan kepada guru sebelum mereka bertanya kepada teman yang lain dalam kelompoknya, meskipun sebenarnya ada anggota kelompoknya yang bisa mengerjakan; mereka juga masih belum memiliki kepercayaan diri yang cukup ketika mereka menjadi tutor/pengajar teman sebaya di dalam masing-masing kelompoknya. Untuk proses pembelajaran matematika dengan strategi koooperatif Tipe STAD memerlukan durasi waktu yang cukup lama bila dibandingkan dengan kegiatan pembelajaran langsung.

Berdasarkan dari kesimpulan deskripsi di atas, peneliti menyarankan agar pembelajaran kooperatif sebisa mungkin tidak terasa asing bagi para anak didik dan mudah untuk diterapkan di sekolah-sekolah, sebaiknya mulai diperkenalkan dari tingkat SD dengan pemilihan konten materi yang sederhana sesuai dengan karakteristik pembelajaran kooperatif. Dan jika perlu, untuk jenjang sekolah dasar ini lebih disederhanakan dalam pelaksanaannya, supaya dapat diterapkan dengan mudah sesuai dengan karakter siswa pada jenjang sekolah dasar. Selain dari itu 
untuk penelitian lanjutan pembelajaran matematika dengan strategi kooperatif mungkin dapat dilakukan kembali dengan berbagai metode yang kemudian kemampuan pemecahan masalah matematik diharapkan dapat ditingkatkan.

\section{DAFTAR PUSTAKA}

Hake, R, R. (1999). Analyzing Change/Gain Scores. AREA-D American Education Research Association's Devision.D, Measurement and Reasearch Methodology.

NCTM. (2000). Priciples and Standards for Schools Mathematics. Reston, Virginia: NCTM.

Ocampo, R. O., \& Bascos-ocampo, R. (2015). Effectiveness of Students' Team Achievement Division on Students'. Attitude Towards Physics, 3(4), 112117.

Pimta. (2009). Factor Influecing Mathematics Problem Solving Ability of Sixth Grade Students. Journal of Social Scinces, 5(4), 381-385.

PISA. (2016). Organisation for Economic Co-operation and Development (OECD).

Polya, G. (1985). How to Solve It. A New Aspect of Mathematic Method (2 ed). New jersey: Pearson Education, Inc.

Roestiya. (2001). Strategi belajar mengajar. Jakarta: PT. Rineka Cipta.

Setiawan. (2006). Model Pembelajaran Matematika Dengan Pendekatan Investigasi. Modul Paket Pembinaan Penataran: Tidak diterbitkan.

Siregar, M. U. M., Syahputra, E., \& Sriadhi. (2019). The Development of Cooperative Type-Based Learning Media of STAD Assisted by Adobe Flash to Improve Spatial Ability of Students in Medan 1 MTs Negeri 1 Model, 10(21), 101-106. https://doi.org/10.7176/JEP

Siswadi. (2018). Peningkatan Kemampuan Pemecahan Masalah siswa SMP Laksamana Martadinata Medan Melalui Pendekatan Matematika Realistik. Jurnal MathEducation Nusantara, 1(1), 32-39.

Suherman, E. (2003). Strategi Pembelajaran Matematika Kontemporer. Bandung: JICA UPI.

Sukayasa. (2012). Pengembangan Model Pembelajaran Berbasis Fase-Fase Polya Untuk Meningkatkan Kompetensi Penalaran Siswa SMP dala Memecahkan Masalah Matematika. Jurnal AKSIOMA, 1(1), 11-24.

Sumarmo, U. (1994). Suatu Alternatif Pengajaran Meningkatkan Kemampuan 
Pemecahan Masalah Matematika.

Sumarmo, U. (2010). Berpikir dan Disposisi Matematik: Apa, Mengapa, dan Bagaimana Dikembangkan pada Peserta Didik. Artikel Pada FPMIPA UPI Bandung.

Wibowo, Rahmat, Wahyudi, \& N. (2016). Penerapan Model Kooperatif Tipe STAD dalam Peningkatan Pembelajaran Bangun Datar pada Siswa Kelas V SD. Kalam Cendekia PGSD Kebumen, 4(1), 1-7.

Widyantini. (2008). Penerapan Pendekatan Kooperatif STAD dalam Pembelajaran Maematika SMP. Yogyakarta: PPPPTK MATEMATIKA. 